\title{
Історія журналістики в часи презентизму: досвід США
}

\author{
Гудошник О. В.
}

\author{
Дніпровський начіональний університет імені Олеся Гончара
}

Дослідження змін темпоральних уявлень останнім часом актуалізувалися в межах технічних наук, у комунікативістиці, історії, психології, культурології та мистецтвознавстві. Поширеними стали практики переосмислення часу історичного, як результат - звернення до явища презентизму, у якому «суспільство переорієнтовується на поточний момент» (Д. Рашкофф), контекстність відтворюється через повсякденний приватний досвід, а емоційність/емпатичність є своєрідним посередником для розуміння минулого. Метод «дослідження життєвих історій» запропонований автором як спосіб представлення історико-журналістського контексту через взаємодію між індивідуальним досвідом і узагальненими практиками та як можливий варіант виходу з неподоланої досі кризи ідентичності дисципліни «Історія журналістики». В американському журналістикознавстві такий міждисциплінарний підхід зреалізовано в діяльності Асоціації освіти в галузі журналістики та масових комунікацій, у просторі академічних дискусій: відповідну тематичну підбірку проаналізовано в журналах Journalism \& Mass Communication Educator (JMCE) та American Journalism. Історія журналістики як дискурс пам'яті очевидців та свідків у статті проілюстрований трьома видами усноісторичних матеріалів: класичні традиційні архіви медіаеліти (колекції Колумбійського університету Columbia University's Oral History Research Office, Інституту медіадосліджень Пойнтера); архіви журналістських об'єднань та спільнот (Фонд «Усні історії» Вашингтонського пресклубу, проєкт пенсільванських журналістів Newspaper Journalists Oral History Program, журналістів Айови lowa Journalists Oral Histories) 3 окремішнім проєктом «Жінки в журналістиці»; на прикладі ресурсу Riptide представлені осучаснені варіанти подання історикожурналістської інформації.

Ключові слова: презентизм; історія журналістики; усна історія; архіви споминів; проєкт «Жінки в журналістиці»; caŭm Riptide.

\section{1. Вступ}

Постановка проблеми. Новітні теорії та підходи до історико-журналістської науки зумовлені складними змінами, що відбулися як в базових галузях журналістики та історії, так і в міждисциплінарному просторі сучасної культури, а ширше - перебувають в полі тяжіння суперечливих і дискусійних теорій змін темпоральних уявлень.

Сприйняття часу усталено спиралося на лінійну схему минуле-сучасне-майбутнє з актуалізаціями (й ідеалізаціями) певних епох: від Золотого часу античності до орієнтації на майбутнє як визначальний чинник європейської філософії XVIII-XX ст. Сьогодні вчені наполегливо говорять про переосмислення історичного часу, про перехід до орієнтованої на сьогодення концепції презентизму, що «складається 3 безлічі прониклих тимчасовостей» (Tamm \& Olivier, 2019). Для сучасного світу, на думку французького вченого Франсуа Артога, одного з перших дослідників нового "режиму історичності», характерна темпоральна конфігурація, коли «народження нового історичного часу начебто завмерло. Звідси, можливо, і сучасний досвід перманентного справжнього, невловимого й майже нерухомого, що намагається, незважаючи ні на що, провести для самого себе власний історичний час». Цей момент і досвід Ф. Артог позначає як презентизм (Hartog, 2008).
Hudoshnyk O., Candidate of Philological Sciences (Ph.D.), Associate Professor, Associate Professor of the Department of Mass and International Communication, e-mail address: gudoshnik_o@fszmk.dnu.edu.ua, ORCID: http://orcid.org/0000-0002-5941-4502, Oles Honchar Dnipro National University, 13, Naykova Str., Dnipro, 49050, Ukraine
Гудошник О.В., кандидатка філологічних наук, доцентка кафедри масової та міжнародної комунікації, електронна адреса: gudoshnik_o@fszmk.dnu.edu.ua, ORCID: http://orcid.org/0000-0002-5941-4502, Дніпровський національний університет імені Олеся Гончара, вул. Наукова 13, Дніпро, 49050, Україна 
Аналіз останніх досліджень. Звернення до зазначеного феномену в міждисциплінарному дискурсі актуалізувалося в 2010-х рр. Засадничою в розумінні презентизму як поширеного явища сучасної культури, економіки, масмедіа, кіномистецтва стала робота відомого дослідника медіавірусів Дугласа Рашкоффа «Шок презентизму: коли все відбувається зараз» (Present Shock: When Everything Happens Now, 2013). Якщо Елвін Тоффлер натиск карколомних змін у 1970 р. назвав футурошоком, то Д. Рашкофф визначає початок XXI ст. як епоху презентизму, коли «суспільство переорієнтовується на поточний момент», а «культура стає ентропійним, статичним гулом усіх, хто намагається вловити момент сковзання» (Rushkoff, 2013, p. 6).

П’ять розділів книжки присвячені осмисленню головних характеристик презентизму: наративний колапс (відмова від лінійності розповіді та аргументації); диджифренія («наші засоби масової інформації та технології заохочують нас перебувати в декількох місцях одночасно»); перемотка («можливість стиснути великі часові відрізки в набагато менші»); фрактальність (відміна причинно-наслідкових зв'язків, «розпізнавання образів у реальному часі»); апокаліпто - тяжіння до пояснення глобальних світових криз через теорії змови («захоплення апокаліптичною сюжетною лінією»).

Узагальнену картину сучасності Д. Рашкофф малює такою: «немає тимчасового фону, на якому можна виміряти наш прогрес, немає розповіді, за допомогою якої можна було б осмислити наші дії, немає майбутнього, до якого ми могли б прагнути, i, мабуть, немає часу розбиратися в цьому» (Rushkoff, 2013, p. 8). Автор пропонує спробувати досягти рівноваги та компромісного балансу: «Знаходити золоту середину між зберіганням та потоком, занурюватися в різні медіа та активності залежно від обставин... ми можемо надати кожному моменту цінності, на яку він заслуговує, і не більше; ми можемо терпіти невизначеність і протистояти спокусі встановити зв'язки та дійти висновків, як ми будемо готові... ми можемо зробити паузу, ми також можемо ії скасувати» (Rushkoff, 2013, p. 109).

Вибуховий інтерес до сприйняття часу в когнітивній науці, комунікації та медіадослідженнях, психології, фізиці, космології та науці про життя зумовив поширення міждисциплінарних наукових підходів (Ekstrand, 2013). Дослідженню презентизму присвячені наукові та популярні роботи істориків, антропологів, філософів, літераторів тощо. Так, у колективній монографії «Переосмислення історичного часу: нові підходи до сучасності» (Rethinking Historical Time: New Approaches to Presentism, 2019) науковці різних галузей ідею множинності темпоральностей втілили в показі мінливих форм часу в історії, мистецтві, археології, політиці, сучасній культурі (Tamm \& Olivier, 2019). Визначення «цінності моменту» як стрижневого фактору презентизму змусило радикально перео- рієнтувати й вектори сучасних історичних досліджень.

Історія як дискурс пам'яті очевидців та свідків

Розуміння історії як теперішнього часу проблематизувало історичний діалог (Walsham, 2017), адже втрачено усвідомлення майбутнього як головного «фокуса, камертона, моделі» (Kurilla, 2017). Тектонічні зміни торкнулися й сприйняття минулого: актуалізується історія як особистісна пам'ять. Усе більше досліджень та наукових розвідок присвячено подіям не далеких часів, а тим, які «суспільство пам'ятає та знає із сімейних історій» (Kurilla, 2017).

Вибудовування єдиного дискурсу через дискретні кейси окремих людських споминів зумовило інтерес до напряму історії пам'яті. В американській історіографії та політології активно поширені практики «історії знизу» - grassroots (з англ. - «корені трави»). Попри давнє побутування терміну (одними 3 перших метафору-визначення використали американські газети часів президентської кампанії Т. Рузвельта), у сенсі найменування громадських організацій grassroots вжито в 2012 р. відомим американським щомісячником McClure's, а в 1994 р. термін набув нового значення через появу інтернет-спільнот (див., напр., книгу Г. Рейнольда «Віртуальна реальність»). У подальшому термін усе більше асоціювався з т. зв. «низовою демократією», поширенням спільнот та об'єднань, які у своїй діяльності спиралися на принципи самоорганізації та партисипативності. Дослідження комеморативних практик журналістських спільнот у США є метою нашої роботи.

Показ "досвіду світу як низки історій», на думку Д. Рашкоффа, допомагає створити відчуття контексту, значущого складника презентизму. При цьому сучасне «середовище невизначеності» зумовлювало розуміння контексту як "широкого прочитання історії» (Spector, 2014, р. 305), де повсякденність реабілітована, а приватний досвід значущий та сенсовий. Такий підхід до логіки повсякденного та приватного якщо не спростовує, то серйозно оскаржує чинну періодизацію турбулентних та спокійних періодів (пастка історичного спокою): «Коли ми припускаємо, що сьогодення - це час непередбачуваної турбулентності порівняно зі спокійним минулим, ми обмежуємо свою здатність вчитися з минулого досвіду» (Spector, 2014, р. 309). У межах тематики дослідження показовими є приклади, наведені Б. Спектором. Так, збільшуючи оптику розгляду начебто «спокійних» періодів в історії преси, вчений уточнює сталу картину світу: при наближенні журналістське повсякдення постає вибухово емоційним, сповненим життєвих трагедій, подвигів і аж ніяк не нудним та нецікавим. Регулярні зміни стратегій, форм власності, технологічні інновації, інформаційні виклики представляють газетярську галузь, на думку дослідника, як турбулентний процес змін та адаптацій. При цьому контекстність передбачає залучення до аналізу не тільки узвичаєних та формалізованих історико- 
журналістських хронологій, а й фактів економічної історії, газетного менеджменту задля підтвердження тези про умовність існування “спокійних» історичних етапів та висновку про динамічність як іманентну якість досвіду. Ідеться не про переписування журналістської історії, а про поглиблене увиразнення історичного процесу як джерела знань. Історична поінформованість упереджує можливі спотворення та неточності, а емоційність вітається презентизмом як чуттєва категорія, своєрідний посередник для розуміння минулого.

Ще одним наслідком культурно-соціальних змін став піднесений майже до абсолюту феномен індивідуалізму, зумовлений втратою ролі нормативного орієнтиру традиційними соціальними інститутами (родина, церква, школа) (Hanitzsch \& Vos, 2016) та переходом від цінностей виживання до цінностей самовираження. У представленні останніх журналістика набула нових ролей як у політичному житті, у сфері повсякденності (споживання, ідентичність та емоції) (Fendler, 2008; Goyanes \& Rodríguez-Gómez, 2018; Peters, 2012), так і в розвитку методик фіксації життєвих історій.

Методи дослідження. Історичний контекст та критичне мислення актуалізували усноісторичний метод дослідження життєвих історій (life history methodology), активно втілений у різних сферах (педагогіка, медицина, освіта, соціологія). Наративний дискурс досліджень життєвого досвіду увиразнював розуміння контексту як різношарової структури, що відображала інституціональні, соціальні, культурні та міжособистісні стосунки. Реконструкція й легітимізація окремих людських «голосів», на думку дослідників (Дж. Райт, Дж. Базул, К. Сірі, І. Лінкольн, М. Ленфорд), доповнює традиційні методології*: «Оповідні дослідження звеличують голоси замовчаних. Але більше того, вони уславлюють біографію як справжнє відображення людського духу, дзеркало для бачення інших себе» (Dhunpath, 2000, p. 550). У 10-томному проєкті опису методів та методологій соціальних наук SAGE Research Methods Foundations запропоновано такі характеристики life history methods.

- Розповідь будується разом дослідником та учасником, які послуговуються кількома джерелами даних.

- Методи збору матеріалу та аналіз даних використовуються комплексно.

- В остаточному документі важливий контекст, оскільки життя учасника та його стосунки з наратором мають бути детально розкриті.

- ...для достовірності необхідна систематична документація кожного етапу процесу дослідження (Tierney \& Lanford, 2019).

\footnotetext{
* У захопленні навіть говорять про прихід постпарадигматичної епохи - narradigm (Dhunpath, 2000). В останні роки усе більше метод співвідносять з ідеями «насиченого я» Дж. Гергена про ускладнення «способів буття» сучасної людини (Gergen, 1991).
}

Актуальність такого підходу зумовлена важливістю усвідомлення взаємодії між індивідуальним досвідом та соціальним контекстом, адже «індивідуальне життя не розгортається ізольовано, а глибоко вкорінене всередині та формується певними спільнотами, культурами та професіями» (WahlJorgensen, 2018, р. 673). Якщо традиційний інтерес до окремих історій медіаеліти в дискурсі історії преси представлений багатоаспектно, то голос «невидимого» журналіста (ті корені трави, про які так багато йдеться в сучасних дискусіях) губиться в часі, не залишаючи шансу побачити неоприявлену історію преси. Не менш значущий фактор - зміни в кліматі професії, які можна вловити через індивідуальній досвід повсякденності. «У нашому постмодерному світі важливо враховувати цінність свідчень, особливо у світлі розуміння того, що в соціально сконструйованій реальності інтерпретація завжди переплітається з фактом» (Brennen, 2009, р. 301).

Сьогодні узвичаєними та поширеними стають різні форми архівації журналістського індивідуального досвіду. Історія журналістики поступово збагачує традиційні інформаційні джерела: до найпоширеніших і загальновідомих (текстові масиви статей, новин, теле-, аудіофайли, біографії та мемуари відомих видавців та журналістів) додаються нові види - усноісторичні архіви, вільний доступ до яких стає умовою взагалі існування пам'яті та сприйняття часу.

Об'єктом вивчення стали три види архівних журналістикознавчих джерел: класичні традиційні (архіви медіаеліти, за Б. Бреннен); архіви журналістських об'єднань та спільнот (ми їх віднесли до типу grassroots) включно з проєктом «Жінки в журналістиці»; на прикладі ресурсу Riptide представлені осучаснені варіанти подання історико-журналістської інформації, архівації споминів та новітні форми долучення аудиторії до проєкту.

\section{2. Результати дослідження}

Відсутність відповіді на карколомні зміни в професії та культурі, використання методології XIX ст. стали критичними для історії журналістики як дисципліни i наукового об'єкту.

Ще в 1974 р. Джеймс Кері, директор Інституту комунікаційних досліджень Іллінойського університету в статті «Проблема історії журналістики» визнав вичерпність традиційної історичної методології та запропонував культурну історію медіа (cultural history of the media), кардинально змінивши медіаісторіографію. Він закликав «провітрити» атмосферу історії журналістики «новими перспективами та інтерпретаціями». Передусім це стосувалося напряму критичної історії журналістики, що в традиції американської історіографії визначалася як частина соціальної, культурної та політичної історії (Nerone, 2011). Але й сьогодні кризу ідентичності не подолано. «Привид приреченості й даремності вічно нависає над нами», гірко зауважила професорка школи журналістики 
Колумбійського університету Енді Тучер, помічниця редактора Columbia Journalism Review, лауреатка найвідомішої премії з усної історії імені Аллана Невінса (Tucher, 2014).

А отже, погодимося з думкою, що історії журналістики «не вистачає чогось, на кшталт системи чи мережі» (Nerone, 2011, р. 19). Варіанти реалізації таких проєктів запропонувала Асоціація освіти в галузі журналістики та масових комунікацій (The Association for Education in Journalism and Mass Communication). Місія Асоціації, як зазначено на офіційному сайті, полягає в «просуванні найвищих стандартів журналістської та масової комунікаційної освіти, представленні якнайширшого спектру досліджень у галузі комунікації,..., захисті та підтримці свободи спілкування з метою досягнення кращої професійної практики та кращої інформованості громадськості». Асоціація об'єднує фахівців з журналістської освіти університетів і коледжів США та Канади, випускає 4 квартальних журнали (!), залучає членів міжнародної спільноти. Заслуговує на увагу децентралізована структура асоціації (скоріше, самоорганізація): відсутня традиційна вертикальна управлінська система. Вільне об'єднання 19 підрозділів та 9 груп за темами, інтересами (представлена навіть спортивна комунікація) дозволяє науковцям і студентам різних університетів та навчальних закладів долучитися до спільних тематичних проєктів, конференцій, майстер-класів і вебінарів, власного ресурсного центру та рекламних акцій.

Окремий інтерес становлять Комісії, що представляють проблемні міждисциплінарні теми (статус меншин, становище жінок тощо), та співпраця з іншими організаціями та спільнотами. Така відкрита система дозволяє не тільки оперативно реагувати на інформаційні виклики часу, але й уводити в простір дискусій різні аудиторії: національні/міжнародні; фахівці/ студенти; теоретики/практики. Найцікавіше відбувається в окремих кластерних групах. Так, відділ історії (The History Division) налічує 300 членів, співпрацює 3 вищезазначеними журналами з історії преси, має власний бюлетень та офіційний журнал асоціації Journalism History (заснований у 1974 р., рецензований, входить до метричної бази Scopus). Вебсайт журналу принципово різниться від узвичаєних форм представлення академічної інформації. Ця відмінність пов'язана з активною роботою подкаста ресурсу з унікальними відвідувачами з 130 країн світу, а задля продажу окремих програм (наприклад, шоу «Чому історія журналістики має значення») залучають ПРфахівців. Потужний розділ рецензій на книжки з історії комунікацій презентує не тільки національну, а й зарубіжну тематику. Отже, в академічному просторі історія журналістики презентована як відкрита до нових ідей комунікаційна система.

Подальший виклад матеріалу ми пов'язали з логікою знов-таки нелінійного підходу до представлення різних видів та способів презентації історії журналістики у форматі усноісторичних life history (детально нами проаналізовано способи медіатизації усноісторичних архівів, точки дотику журналістики та усної історії (Hudoshnyk, 2021; Hudoshnyk, 2021a)). Близькою для нашого розуміння ролі усноісторичних документів у сучасному світі стала міжнародна конференція «Усна історія та медіа», організована Товариством усної історії Великобританії, де в руслі вибухового інтересу до історії пам'яті були виокремлені сесії «Mainstream Oral History: Oral History and Mass Media» та "Memories of Media», "Reinterpreting (through) Oral History». У межах «Media, Community and Locality» презентовано засоби документації спільнот, роль усноісторичних документів у русі активізму. «Взаємозв'язок між усною історією та засобами масової інформації також можна побачити в тому, як усну історію використовували для вивчення історії та досвіду самих засобів масової інформації, а проєкти усної історії представляли розвиток медіакомпаній та організації», - йшлося в установчих документах конференції.

Академічний пошук у царині нашої тематики усноісторичний дискурс в історії преси - має вже свій літопис і знаних авторів. Однією з перших звернулася до згаданої теми Б. Бреннен (Brennen,1996), яка запропонувала абрисні характеристики викладу проблеми, проаналізувала причини інтересу до збору усних історій. Дослідниця пропонує два дискурси усноісторичних архівів, які дуже умовно ми визначили як класичний дискурс медійних еліт та різнотематичні, гендерні, регіональні grassroots архіви.

Професійний зріз життя медіаеліт та історії прийняття рішень в галузі 3МІ ставить за мету хронікалізацію біографічних історій редакторів, видавців, власників медіа. Він представлений колекцією усноісторичних досліджень Колумбійського університету (Columbia University's Oral History Research Office). Тут зберігаються інтерв'ю з відомими Д. Пулітцером, А. Сінклером, У. Ліппманном. У межах проєкту афроамериканської історії журналістики цього університету були впорядковані інтерв'ю з засновниками афроамериканської журналістки: Елоїз Бенкс, Вільямом А. Фоулксом, Джорджем Шуйлером та Честером Вашингтоном (Brennen, 1996, р. 573). Інтерв'ю та спомини Алана Ньюгарта, голови Gannett Company, Бена Бредлі, виконавчого редактора The Washington Post, представлені в Інституті медіадосліджень Пойнтера (The Poynter Institute for Media Studies, St. Petersburg, Florida).

Окремий напрямок фіксації журналістської роботи - президентські бібліотеки та архіви, де зібрані тексти інтерв'ю президентів, їхні інавгураційні промови та виступи, а додатково - усноісторичні свідчення журналістів, що працювали над підготовкою таких інтерв'ю. Ці матеріали зберігаються в бібліотеках Герберта Гувера (Herbert Hoover Library Oral History Collection), Гаррі Трумана (Harry S. Truman Library Oral History Collection in Independence, Missouri), Джона Кеннеді (The John F. Kennedy Library Oral History 
Collection in Boston, Massachusetts), Лінди Джонса (Lyndon Baines Johnson Library Oral History Collection in Austin, Texas) (Brennen,1 996, p. 575).

Другий напрям - grassroots - пов'язаний із збором інформації та інтерв'юванням звичайних журналістів для розуміння процесів, що відбувалися в країні (наприклад, рухи за громадянські права 19601970 рр.) та регіонах. Варіанти представлення такого журналістського досвіду різноманітні, що підтверджує тезу про великий внесок рядових журналістів у становлення медіаіндустрії, а це своєю чергою актуалізує проблему впливу журналістики як професійної ідентичності на журналістську індивідуальність. Так, у становленні кар'єрних портфоліо дослідниця Л. ВальЙоргенсен пропонує ураховувати підхід «історії життя», який дозволяє зрозуміти «взаємодію між індивідуальним досвідом та соціальним контекстом для досягнення більш широкого колективного досвіду» (Wahl-Jorgensen, 2019).

Локальні проєкти усноісторичних архівів у форматі grassroots ми розглянули на прикладі об'єднань журналістів окремих штатів. Одразу зауважимо, що більшість цих проєктів належить до університетських архівів і пов'язана з діяльністю університетських факультетів/шкіл журналістики та комунікації. Так, бібліотека Університету штату Айова містить понад мільйон цифрових об'єктів, серед яких, окрім традиційних наукових видань та книг, - давні мапи, атласи, фото та газети, рідкісні видання (щоденники та листи Громадянської війни, Першої та Другої світової війни, колекція ранніх рукописів), близько 13 тис. карикатур, приклади образотворчого мистецтва, навіть екзотична колекція циліндрів та зображень шотландських горців.

Усноісторичний архів містить 25 тис. об'єктів, зібраних за тематичними напрямами історії праці, руху фанів наукової фантастики, історії Айови, біографічні добірки. Журналістська тематика представлена газетними вирізками, газетярськими карикатурами, розділом “Усні історії журналістів Айови» (lowa Journalists Oral Histories), що містить матеріали відеоінтерв'ю 3 36 журналістами-новаторами про становлення кар' $\epsilon$ ри, політику в редакції з 1998 по 2005 рр.

Спочатку файли були записані на DV-стрічку, а потім перекодовані у формат WMV. Зазвичай це глибинні біографічні інтерв'ю з максимальною деталізацією умов роботи, як-от: трудомістке обслуговування лінотипа, структура редакцій, обов'язки ії членів, відносини між ними, ставлення до пенсіонерів, зміни журналістського життя після появи телебачення, перші скорочення та гонитва за тиражами та рейтингами. Наявні навіть замальовки буденного життя редакції, де стояв запах газетного паперу, чорнил та тютюну, бо всі палили, а стіл був у плямах від недопалків. Особливу увагу приділяли умовам праці, роботі профспілок, фінансовим відносинам, становищу жінок в редакції. $€$ фактурні яскраві історії, сповнені емоцій та цікавих спостережень, з динамічними діалогами, портретними нарисами та смішними життє- вими замальовками чи анекдотами; в інших - порушено складні дискусійні питання та містяться неполіткоректні оцінки (про нерозголошення яких, до речі, $\epsilon$ попередження на сайті). Деякі інтерв'ю - сухий виклад фактів із максимально докладним описом та деталізацією професійного повсякдення, матеріали інколи переобтяжені несуттєвими моментами та подробицями. На прикладі архіву стає зрозумілим причини подальших змін передусім у процесі архівування та структурі представлення матеріалів. Сучасні вимоги до обробки інформації вимагають чітких описів, логічного структурування, скорочення текстового матеріалу й можливостей тематичних добірок за тегами та пошуковими алгоритмами.

Задля порівняння ми дослідили усноісторичну колекцію журналістів штату Пенсильванія (Newspaper Journalists Oral History Program), ініційовану в 2005 р. Департаментом журналістики штату, громадським фондом та факультетом журналістики Університету штату Пенсильванія «задля збереження спадщини журналістів та газет штату». 19 інтерв'ю представляють історії життя провідних журналістів місцевих 3МІ: особливості роботи редактора локальної газети, новинного репортера, політичного, спортивного оглядача, редактора відділу, критика та ін. Представлені інтерв'ю стандартизовані за тематикою питань: біографічні відомості, початок і розвиток журналістської кар'єри, набуття професійного досвіду через розслідування, життєві історії, відносини с колегами, керівництвом. Важливе місце посідають спомини про відомі політичні події, до яких журналісти були дотичні (війна у В'єтнамі, Шестиденна війна, резонансні редакційні розслідування, відзначені Пулітцерівською премією). Інтерв'ю ретельно розшифровані й викладені у вільний доступ. Вдала навігація сайта, стильова єдність, функціональні та інформативні анонси, довідковий матеріал дозволяють легко орієнтуватися в архіві, вільний доступ до матеріалів спрощує використання документів.

Інший підхід до усноісторичних свідчень демонструє Національний пресклуб, що об'єднав колекції журналістських інтерв'ю Комітету усної історії (більше 150 записів) та Фонду «Усні історії» Вашингтонського пресклубу. Більшість цих матеріалів представлені у відео чи аудіоформатах і не мають стенограм. Більше того, вони закриті для вільного доступу, лише організатори “уповноважені дублювати або публікувати будь-які закриті матеріали» (з офіційного сайту). Тегування матеріалів, опис, анонси відсутні; архівні записи доступні для членів пресклубу. За умови виконання додаткових вимог дослідники можуть ознайомитися 3 документами. Це ускладнює аналіз архівних даних; викладені ознайомчі матеріали засвідчують використання в практиці архіву традиційних для глибинного інтерв'ю розлогих споминів з численними подробицями та уточненнями; надають об'ємності оповідям і громіздкі «вільні міркування» авторів щодо майбутнього журналістики, політичних реалій, екології. 
Окремим напрямком журналістської історіографії в жанрі grassroots $€$ аналіз досвіду жінок-журналісток та презентація його як альтернативи наративу чоловічої журналістської професії (Beasley, 2001). Зазначимо, що створення феміністичних архівів має давню історію: у 1935 р. був заснований Всесвітній центр жіночих архівів (1935-1940рр.), що сприяло формуванню феміністичної історіографії, жіночого архівного руху та архівної науки, особливо щодо маргіналізованих груп (Severson, 2018).

Дослідники цього тематичного пласту пропонують розширити набір критеріїв оцінки діяльності жінокжурналістів з огляду на складність громадських ролей, що вони виконують (Beasley, 2001, p. 208). Робота всередині соціальних структур, орієнтованих на чоловічий підхід до подання новин, змусила жінок проходити різні етапи становлення власної гендерної визначеності: від компенсаторної до рівноправної, від поодиноких біографій до потужних об'єднань. Ці спільноти активно сприяли створенню архівів усних історій та стрімко урізноманітнили гендерно монохромну картину світу американської журналістики. Використання міждисциплінарного підходу гендерних, родинних, жіночих досліджень дозволило довести вплив журналісток на демократизацію простору публічної комунікації порівняно з "доволі жорсткою структурою новинних формул та уявлень, презентованих чоловіками» (Beasley, 2001, p. 118). Процес формування нових соціальних жіночих ролей відображено в біографіях, історіях жіночих журналістських об'єднань, в особливій стилістиці жіночого голосу в контексті часу (Beasley, 2001, p. 208).

Дослідники пропонують чотириступеневу концепцію актуалізації жіночої історії: компенсаційний етап (ідентифікація невідомих історичних фактів); професійні здобутки (оцінка досягнень героїні); транзитивний (погляд на історичні категорії з точки зору жіночої перспективи); синтез (інтеграція чоловічого та жіночого досвідів). Архіви жіночих організацій і пресових клубів (Women's National Press Club, New York Newspaper Women's Club, National Women and Media Collection at the University of Missouri Columbia, Women's Institute for Freedom of the Press), біографічні свідчення та спомини стають джерелом інформації для вибудовування жіночого дискурсу в американській історії журналістики. Цей напрям отримав назву History of Women in Journalism, усноісторичні архіви одні з його найпотужніших джерельних баз.

Найвідомішим став проєкт усної історії «Жінки в журналістиці» (Women in Journalism), започаткований у 1986 р. Жіночим національним пресклубом, заснованим для підтримки рівних редакційних прав жінок. 3 майже 60 інтерв'ю на сьогодні оцифровано й викладено у вільний доступ 37. Серед представлених авторок - піонерки ранньої жіночої журналістики, поборниці громадянських прав та знаменитості у світі телевізійного мовлення - ті, кого вважають важливими постатями в історії жіночої журналістики, починаючи 3 1920-х рр. (з офіційного сайта фонду). Інтерв'юерами виступили журналісти, фахівці та консультанти з усної історії. Усі стенограми та відео зберігаються в бібліотеці Колумбійського університету, бібліотеці Національного пресклубу, частково в бібліотеках 9 університетів США.

Сайт проєкту засвідчує системну роботу, джерела згруповані за такими напрямками.

- Жіночий рух, боротьба за права жінок та позов до The New York Times щодо дискримінації за ознакою статі.

- Расизм, ера громадянських прав та позов Бенільди Росаріо проти дискримінації меншин у Times.

- Висвітлення основних американських політичних подій XX ст.

- Зміни в журналістській етиці, технологіях та суспільстві.

Архів - безцінна скарбниця історикожурналістської інформації: тут представлені спомини свідків пресконференцій Елеонори Рузвельт (а вона запрошувала на них лише жінок-репортерок); історія Бет Кембел Шор, безстрашної stunt-girl reporter, єдиної серед 88 чоловіків-репортерів американської агенції The Associated Press; інтерв'ю з Кетрін Бібі Гарріс, яка висвітлювала викрадення Ліндберга та народження ООН; інтерв'ю з найвідомішою спортивною кореспонденткою Мері Гарбер; Еленою Гудман, Пулітцерівською лауреаткою, чиї дописи публікували більше 400 американських газет. Поруч з цими життєвими історіями - маловідомі подробиці колективного позову проти впливової The New York Times щодо дискримінації за ознакою статі (New York Times vs Boylan et al.) чи інтерв'ю військового кореспондента часів Другої світової Хелен Кіркпатрік Мілбанк, яке $\epsilon$ готовим «матеріалом для грандіозного романтичного роману або захоплюючого епічного фільму про війну». Такі живі архівні свідчення сповнюють історію журналістики живими подробицями реального повсякдення героїв, увиразнюють курс, що традиційно складно вписується в сучасні вимоги візуальності та швидкоплинності.

Докладний аналіз архіву з урахуванням вимог цифрової журналістики здійснила в 2018 р. шведська дослідниця Парніла Северсон. Серед визначених нею особливостей архіву відзначимо: орієнтація лише на запис відомих (виняткових та визнаних) журналісток актуалізує потребу в демократизації підходу до колекції, тобто потребує представлення не тільки центральний дискурс жіночої історії преси, а й «периферійні» спомини; гостро необхідним бачиться дослідниці розширення бази й урізноманітнення представлених матеріалів та активні популяризаційні заходи: «вимагати, створювати, залучати цифрові архіви, що містять питання переписування історії журналістики» (Severson, 2018).

I наостанок, нам вдалося знайти проєкт осучасненого викладу історико-журналістського матеріалу, який за структурою, проблематикою, перспективністю й обмеженістю одночасно унаочнив ідеї презентизму. 
Теперішнє використання усноісторичних джерел має суттєві відмінності від класичних вимог oral history й продиктоване новітніми технологіями подання матеріалу й залученням аудиторії до співпраці. Новітній формат у тематичному представленні усно-історичних свідчень демонструє проєкт Riptide, де четверо «ветеранів цифрової журналістики та медіа» - Джон Хьюї, Мартін Нісенгольц, Пол Саган, Джон Геддес - опитали більше 80 людей, які відіграли «важливу роль на перетині медіа та технологій». Метафора назви - riptide як турбулентна небезпечна зона в морі, де зустрічаються течії, буремний розрив припливу - пояснена в підзаголовку ресурсу "Усна історія епічного зіткнення журналістики та цифрових технологій з 1980 року до сьогодні». Цей проєкт створено за сприяння Центру преси і державної політики Джоан Шоренштейн та лабораторії журналістики Німана в Гарварді в 2013-2015 рр.

Перед нами ускладнений різноспрямований ресурс, що поєднує історичні факти, усноісторичні інтерв'ю та сучасні журналістські підходи до представлення аналітичних висновків, багатий додатковий матеріал і можливості для читача самостійно провести власне дослідження, створити свій історикожурналістський наратив. На сайті представлені два великих підрозділи із загальним заголовком «Що насправді сталося з новинним бізнесом». У першому томі «CEOs, Coders, News Execs, Disrupters» (15 частин) досліджено вплив соціальних мереж на новини, представлені хронологічні віхи розвитку медіаіндустрії від руйнування традиційних комерційних моделей, появи безкоштовного новинного контенту, боротьби за онлайн-аудиторію до епохального зіткнення традиційної журналістики та технологій, що кардинально перебудовують новітнє сприйняття рекламних платформ, соціальних мереж як основи новинного бізнесу. Висновок об'єднує намагання бути оптимістичними (як-от слова Ніка Лемана, декана школи журналістики Колумбійського університету, "Усе якось вийде») і чітке усвідомлення складності переходу від застарілого інформаційного бізнесу до нових реалій. Ці реалії автори визнають як найшвидшу розривну течію сучасного інформаційного світу, той самий riptide, винесений у назву ресурсу: «Наступний повний місяць, наступний ураган, черговий прорив у цифрових медіа - здається, обов'язково знищить багатьох знайомих плавців, перш ніж це все якось вдасться" (Volume 1. Chapter 15. Time Will Tell (Riptide, 2013\& 2015)).

Другий том присвячено журналістам, що висвітлюють цифрову епоху, та наскрізній проблемі взаємодії журналістки та новинного бізнесу. Ідеї впливу презентизму на розуміння часу та невиразність майбутнього, що певною мірою знімає з порядку денного прогностику, виявилось у логіці цього ресурсу повною мірою, адже «Репортерам платять за те, щоб бути свідками, а не оракулами. Їх прогнози іноді можуть бути правильними, але їх основний обо- в'язок - точно описати те, що відбувається» (Volume 2. Reporters Covering the Digital Era Assess the News Business's Struggle to Transform. (Riptide, 2013\& 2015)).

Автори визнають іманентну хибність будь-яких прогнозів, для них важливо замість невдячної та нездійсненої справи «вдивлятися в кришталевий шар» надати слово досвідченим зацікавленим розумним свідкам. У цій презентації різних точок зору автори пропонують три рівня прочитання матеріалів.

Традиційний усноісторичний (документальний) рівень. Представлені ретельно задокументовані більше 80 глибинних інтерв'ю (англ. - in-depth interviews) 3 редакторами $3 \mathrm{MI}$, директорами компаній, засновниками видань і мереж, оглядачами, науковцями, провідними журналістами, репортерами, лауреатами та номінантами Пулітцерівської премії. Серед них: директор AOL Tім Армстронг, редактор The Washington Post Марті Барок, генеральний директор Twitter Дік Кастоло, директор Hearst Corp. Уілл Херст, розслідувачка ProPublica Джулія Енгвін та ін.

Кожний персональний файл містить фото героя, коротку біографічну довідку з головними здобутками автора в медійній галузі; мультимедійний варіант інтерв'ю; текстову розшифровку з частковим редагуванням (виправлено обдрук, помилки) та пропози-цією читачам долучитися до технічної коректури тексту. Інтерв'ю зі схожої проблематики винесено в праву панель екрану - під час ознайомлення можна самостійно розширити дискурс дискусійної теми й скористатися додатковими матеріалами.

Журналістський рівень спирається на жанрову природу окремих розділів, виконаних у формі лонгрідів з додатковими матеріалами, гіперпосиланнями, цитатами, інфографікою, фото, часовою шкалою та допоміжною інформацією. Цей абсолютно самостійний завершений жанр надає повне уявлення про авторське розуміння наслідків впливу технологій на журналістський бізнес, подано історію та подальшу ґенезу проблеми, чітко окреслене коло професіоналів, чиї експертні висновки обгрунтовані та цікаві, а прояви впливів конкретизовані прикладами американського та світового медіаринків. Розлогі інтерв'ю скорочені до влучних цитат, зазвичай на одне речення, що відповідає композиції та структурі жанру, вони виконують ілюстративну функцію та увиразнюють зіткнення різних думок чи поглядів. У розділах трапляються «цитатні дуелі», авторський текст слугує лише «підводкою» для представлення сторін дискусії. Цей рівень авторського журналістського підходу до сприйняття проблеми може бути розширено/ поглиблено/ опротестовано самостійною співпрацею читача - йдеться вже, власне, про третій рівень контенту.

Залучення аудиторії, сайт як медіатор самостійного пошуку. Не випадково автори так багато говорять про становлення нової аудиторії. Звичайний читач обмежиться лише журналістським матеріа- 
лом, а зацікавлений і небайдужий може пройти самостійно мережею свідчень та думок героїв інтерв'ю, залучивши додаткову літературу (запропоновану до кожного розділу), ознайомитися з фаховими коментарями медійників США в газетних інтерв'ю (цей пласт також залучено до проєкту), прочитати книжки, наукові розробки Колумбійської школи журналістики, навіть зайти на персональні блоги з вдалими формулюваннями та думками 3 окремих питань. Таке поглиблене занурення в заявлені теми, чітке визначення базових точок на самостійному дослідницькому шляху - чи не найвдаліше відкриття ресурсу. Зважаючи, що формат було запропоновано в 2013 р., можна очікувати, що усні історії отримають нове життя в журналістських матеріалах й у персональних розвідках зацікавлених читачів. Тим більше, осучаснення усноісторичних архівів стає узвичаєною практикою світового інформаційного простору (маємо на увазі проєкти The COVID -19 Oral History Project, Oral History Narrative and Memory Project, Journal of the Plague Year, pecypc StoryCorps та ін.).

\section{3. Обговорення}

В американському журналістикознавстві проблеми специфікації та осучаснення історичних дисциплін активно виносилися в простір публічних та професійних дискусій через академічні видання та журнали професійних спільнот. Найвідомішим серед них став заснований у 1944 р. Journalism \& Mass Communication Educator (JMCE), присвячений освіті в галузі журналістики, зв'язків з громадськістю, реклами, масової комунікації, медіадосліджень та суміжних галузей. 31972 р. в журналі вийшло близько двох десятків статей, присвячених проблемі (не) актуальності історії преси в системі журналістської освіти: від опису новітніх методик подання історичної аргументації до зміни філософії та загальної проблематики дисципліни. У руслі нашої тематики цікаві думки викладача з Університету Іллінойсу Джона Нерона про поширене уявлення сьогодення, як такого, що просто й природньо прийшло з минулого. Але розуміння конфліктності, різноманітності та контексності як історично іманентних якостей $€$ на сьогодні необхідною ознакою історичної грамотності й дозволяє, як стверджує дослідник, вільно «прочитувати» не тільки минуле, а й сучасність (Nerone, 1990).

У 2011 р. інший академічний журнал American Journalism виніс на обговорення проблеми історії журналістики як університетської дисципліни та наукового напрямку. Серед головних проблем редакторка видання Барбара Фрідман (Friedman, 2011) визначила такі: неврахування міждисциплінарної природи історії; зміни сучасних стандартів журналістики та оцінки минулого; відсутність відкритих дискусій, небажання виходити за межі «зони комфорту»; необхідність визнання міждисциплінарних підходів аналізу; самозамкненість, відсутність широкої ауди- торії; звуження джерельної бази (передусім архівної); необхідність пошуку близьких «сусідів» та союзників у розвитку історико-журналістської методології та методики.

Свої інституціональні ознаки історія журналістики отримала під час інтеграції до університетських програм і одночасного формування двох потужних векторів розвитку. 3 одного боку, історія журналістики сприймалася як частина загальної історії, з максимальною акцентуацією на національному продукті: «Як результат - історія журналістики має тенденцію бути національною» (Nerone, 2011, р. 19). 3 іншого - відбулося поступове усвідомлення специфіки журналістики як комунікативної практики, «особливо важливої форми не тільки передачі інформації в просторі, але й збереження смислів або структур почуттів» (Nerone, 2011, р. 12). У 2013 р. дослідниця Джованна Дель Орто, продовжуючи ідеї Д. Галліна та П. Манчіні, пропонувала виходити за межі національних історій та досліджувати зв'язок між ЗМІ та міжнародною комунікацією через співставлення медіасистем (Dell'Orto, 2013). Вже згадувана Енді Тучер відродження інтересу до історії журналістики пов'язувала 3 тренуванням історичного уявлення, 3 активним залученням до курсів, окрім узвичаєного текстового аналізу, контекстних досліджень та цифрових баз даних. «Історія журналістики має значення, тому що ми не можемо використовувати журналістику, щоб знати історію або знати про сьогодення - не знаючи, як журналістика працювала в історії» (Tucher, 2014). Увести в простір історії журналістики моделі та концептуальні підходи культурологічного аналізу пропонує дослідник Томас Шмідт (Schmidt, 2016). Йому ж належить аналіз становлення емоційності як професійної норми та розвитку наративної журналістики в історії американської преси 1960-1990 рp. (Schmidt, 2021).

\section{4. Висновок}

Дискурс сучасної історико-журналістської науки все виразніше демонструє внутрішні проблеми своєї ідентифікації та активно звертається до новітніх засобів вписування в мінливий інформаційний простір журналістики. Презентизм, як результат фундаментальних зрушень у сприйнятті часу, попри дискусійність визначення, певною мірою пояснює відхилення за віссю класичне-модернове, минуле-майбутнє, виводить на перше місце новий вимір протистояння: заміна «віддалений, неемоційній, чужий» на «свій, чуттєвий, знаний, близький». Цей простір споріднених «голосів», «ціннісних моментів» найяскравіше увиразнює усна історія, що пропонує в історикожурналістському дискурсі різні формати кодифікації знань: від громіздких архівів життєвих історій до миттєвих реакцій сучасних мобільних застосунків та соціальних мереж, від епічних форм розлогих глибинних інтерв'ю до динамічних лонгрідів та історичного сторітелінгу. 


\section{References}

Beasley, M. (2001). Recent directions for the study of women's history in American journalism. Journalism Studies, 2 (2), 207-220. https://doi.org/10.1080/14616700117394.

Brennen, B. (1996). Toward a history of labor and news work: The use of oral sources in journalism history. The Journal of American History, 83(2), 571-579. https:// doi.org/10.2307/2944949.

Brennen, B. (2009). The future of journalism. Journalism, 10(3), 300-302. https://doi.org/10.1177/1464884909102584.

Dell'Orto, G. (2013). Go big or stay home: Why journalism historians matter to understanding international affairs. American Journalism, 30(3), 301-307. https:// doi.org/10.1080/08821127.2013.816900.

Deuze, M., \& Witschge, T. (2017). Beyond journalism: Theorizing the transformation of journalism. Journalism, 19(2), 165-181. https://doi.org/10.1177/1464884916688550.

Dhunpath, R. (2000). Life history methodology: "narradigm" regained. International Journal of Qualitative Studies in Education, 13(5), 543-551. https:// doi.org/10.1080/09518390050156459.

Ekstrand, V. S. (2013). The Presentist media landscape and the practice of doing history. American Journalism, 30(4), 441-449. doi.org/10.1080/08821127.2013.846708.

Fendler, L. (2008). The upside of presentism. Paedagogica Historica, 44(6), 677-690. https:// doi.org/10.1080/00309230802486150.

Friedman, B. (2011). Editor's note. American Journalism, 28 (4), 5-6. https:// doi.org/10.1080/08821127.2011.10677799.

Gergen, K. J. (1991). The saturated self: Dilemmas of identity in contemporary life. Basic Books.

Goyanes, M., \& Rodríguez-Gómez, E. F. (2018). Presentism in the newsroom: How uncertainty redefines journalists' career expectations. Journalism, 22(1), 52-68. https:// doi.org/10.1177/1464884918767585.

Hanitzsch, T., \& Vos, T. P. (2016). Journalism beyond democracy: A new look into journalistic roles in political and everyday life. Journalism, 19(2), 146-164. https:// doi.org/10.1177/1464884916673386.

Hartog, F. (2008). Poryadok vremeni, rezhim istorichnosti [The order of time, modes of historicity]. Neprikosnovennyy zapas, 8. https://magazines.gorky.media/ $\mathrm{nz} / 2008 / 3 /$ poryadok-vremeni-rezhimy-istorichnosti.html (in Russian).

Hudoshnyk, O. (2021). Mediatyzatsiia usnoi istorii novi formaty ta platformy [Mediatization of oral history: new formats and platforms]. Media sphere: local and global. Collective monograph. Dnipro, Jurfond (in Ukrainian).

Hudoshnyk, O. (2021a). Komemoratyvni mediapraktyky v period pandemii [Commemorative media practices during the pandemic]. State and Regions. Series: Social Communications, 2(46), 29-34. https://doi.org/10.32840/ cpu2219-8741/2021.2(46).5 (in Ukrainian).

Kurilla, I. (2017). Istoriya $v$ epokhu pobedivshego prezentizma: instrument borby za identichnost, resurs dlya politiki ili nauchnoye znaniye? [History in the era of victorious presentism: an instrument of the struggle for identity, a resource for politics, or scientific knowledge?] Lecture at the Sakharov Center. http://sakharov.gaidarfund.ru/ articles/2828/tab1 (in Russian).

Lincoln, Y., \& Lanford, M. (2018). Life history's second life. Qualitative Inquiry, 25(5), 464-470. https:// doi.org/10.1177/1077800418817835.

Nerone, J. (1990). The problem of teaching journalism history. The Journalism Educator, 45(3), 16-24. https:// doi.org/10.1177/107769589004500302.

Nerone, J. (2011). Does journalism history matter? American Journalism, 28(4), 7-27. https:// doi.org/10.1080/08821127.2011.10677800.

Peters, C. (2012). Journalism to go. Journalism Studies, 13(56), 695-705. https:// doi.org/10.1080/1461670x.2012.662405.

Riptide, (2013-2015). https://www.digitalriptide.org/.

Rushkoff, D. (2013). Present shock: When everything happens now. Penguin.

Schmidt, T. (2016). The circuit of culture: A model for journalism history. CM: Communication and Media, 11(38), 7188. https://doi.org/10.5937/comman11-9516.

Schmidt, T. R. (2021). 'It's OK to feel': The emotionality norm and its evolution in U.S. print journalism. Journalism, 22 (5), 1173-1189. https:// doi.org/10.1177/1464884920985722.

Severson, P. (2018). The politics of women's digital archives and its significance for the history of journalism. Digital Journalism, 6(9), 1222-1238. https:// doi.org/10.1080/21670811.2018.1513336.

Spector, B. (2014). Using history Ahistorically: Presentism and the tranquility fallacy. Management \& Organizational History, 9(3), 305-313. https:// doi.org/10.1080/17449359.2014.920261.

Tamm, M., \& Olivier, L. (2019). Rethinking historical time: New approaches to Presentism. Bloomsbury Publishing.

Tierney, W. G., \& Lanford, M. (2019). Life History Methods. In P. Atkinson, S. Delamont, A. Cernat, J.W. Sakshaug, \& R.A. Williams (Eds.), SAGE Research Methods Foundations. www.doi.org/10.4135/9781526421036750846.

Tucher, A. (2014). Why journalism history matters: The gaffe, the "Stuff," and the historical imagination. American Journalism, 31(4), 432-444. https:// doi.org/10.1080/08821127.2014.969671.

Tyng, C. M., Amin, H. U., Saad, M. N., \& Malik, A. S. (2017). The influences of emotion on learning and memory. Frontiers in Psychology, 8:1454. https:// doi.org/10.3389/fpsyg.2017.01454.

Wahl-Jorgensen, K. (2018). Challenging presentism in journalism studies: An emotional life history approach to understanding the lived experience of journalists. Journalism, 20(5), 670-678. https:// doi.org/10.1177/1464884918760670.

Walsham, A. (2017). Introduction: Past and ... Presentism. Past \& Present, 234(1), 213-217. https:// doi.org/10.1093/pastj/gtw054.

Washington Press Club Foundation. https://www.wpcf.org/ project-overview.

Wright, J. S. (2019). Re-introducing life history methodology: An equitable social justice approach to research in education. Research Methods for Social Justice and Equity in Education, 177-189. https://doi.org/10.1007/978-3-03005900-2_15. 


\section{Hudoshnyk O. History of journalism in the times of presentism: the experience of the United States}

Studies of changes in the perception of time have recently become relevant in the field of the technical sciences as well as in communication studies, history, psychology, culturology and art history. Rethinking historical time is a practice that has become especially common and resulted in the phenomenon of presentism, which means that the "society is reoriented to the present moment" (D. Rashkoff), contextuality is reproduced through everyday private experience, and emotionality/empathy acts as a mediator in the understanding of the past.

The author suggests applying the life story research method as a mean of presentation of the historical and journalistic context through the interaction between individual experience and generalised practices as well as a possible way out of the identity crisis, which still has not been overcome.

In American journalism, interdisciplinarity is especially evident in the activities of the Association for Education in Journalism and Mass Communication and in the field of academic discussions: the relevant thematic selection is analysed in the journals, such as Journalism \& Mass Communication Educator and American Journalism. The history of journalism as a discourse in the memory of witnesses is represented in the article by three types of oral history materials: classical traditional archives of the media elite (collections of Columbia University Centre for Oral History Research, Poynter Institute for Media Studies); archives of journalists associations and communities (Washington Press Club Foundation, Pennsylvania Newspaper Journalists Oral History Program, lowa Journalists Oral Histories), with special attention to the Women in Journalism project; the Riptide resource, which is an example of updated versions of the presentation of historical and journalistic information.

Keywords: presentism; history of journalism; oral history; archives of memories; Women in Journalism project; Riptide website. 